\title{
Legume Establishment on Strip Mined Lands in Southeastern Montana
}

\author{
JERRY L. HOLECHECK, EDWARD J. DEPUIT, JOE G. COENENBERG, AND RAUL VALDEZ
}

\begin{abstract}
Research was conducted on topsoiled strip mined lands at Colstrip, Mon., over a 6-year period to evaluate germination, survival, productivity, and cover characteristics of Eski sainfoin (Onobrychis viciaefolia), Lutana cicer milkvetch (Astragalus cicer), birdsfoot trefoil (Lotus corniculatus), and ranger and spreader alfalfa (Medicago sativa). Nitrogen and phosphorus fertilizer were applied at a low rate during the first year of study. None of the experimental units received irrigation. Lutana cicer milkvetch and both varieties of alfalfa demonstrated good establishment, survival, canopy cover, and productivity characteristics. Eski sainfoin showed good initial establishment but declined in following years. Birdsfoot trefoil appeared to be unsuitable for revegetation of mined lands at Colstrip. Spreader alfalfa was superior to ranger alfalfa in the parameters evaluated. Lutana cicer milkvetch showed much potential for mined lands revegetation in the study area because of site stabilization, persistence, palatability, nitrogen fixation, and productivity characteristics.
\end{abstract}

Revegetation of coal strip mined lands in the Northern Great Plains has received considerable attention in recent years due to acceleration of mining and associated land disturbance. A number of investigations have been reported comparing the establishment of different grass species on strip mined lands in the Northern Great Plains (Sindelar et 1973; Farmer et al. 1974; Meyn et al., 1976; DePuit et al. 1977; DePuit et al. 1978; DePuit and Coenenberg, 1979; Holechek 1981, 1982; Holechek et al. 1981a,b). Several legumes have shown potential on strip mined lands at Colstrip, Mon. and other mining locations in the Northern Great Plains (Sindelar et al. 1973; Sindelar et al. 1974; Dollhopf and Majerus 1975; DePuit and Coenenberg 1977; Holechek 1981, 1982). These include ranger and spreader alfalfa (Medicago sativa), Eski sainfoin (Onobrychis viciaefolia), and Lutana cicer milkvetch (Astragalus cicer). However, specific research has not been conducted to compare the effectiveness of these species in revegetating strip mine lands in the Northern Great Plains. The objectives of this study were to determine the emergence, survival, productivity, and cover characteristics of the four legume species previously mentioned and birdsfoot trefoil (Lotus corniculatus) on mined lands at Colstrip, Mon.

\section{Methods}

During the spring of 1975,15 experimental plots, $10 \times 10 \mathrm{~m}$, were established on strip mined land at Colstrip that had been previously graded, ripped, and topsoiled. The experimental design

\footnotetext{
Authors are assistant professor. Department of Animal and Range Sciences, New Mexico State University, Las Cruces; research plant ecologist; research associate, Department of Animal and Range Sciences, Montana State University, Bozeman; and assistant professor, Department of Wildlife Science, New Mexico State University, Las Cruces. Edward $J$. DePuit is currently associate professor of range management, Range Management Division, University of Wyoming, Laramie, and Joe G. Coenenberg is currently vegetation specialist with Western Energy, Colstrip, Mon.

This research was funded by the U.S. Forest Service Surface Environment and Mining (SEAM) Program and was part of Cooperative Agreement No. 16. (USC 581:58 (a-58 (i); additional support provided by the Western Energy Company, Colstrip, Mon.

Manuscript received July 25, 1980.
}

included three blocks of five plots. The five species/varieties were randomly assigned to plots in each block. Seeding was accomplished by broadcasting and then cultipacking on May 3, 1975. All species were seeded at the rate of 538 pure live seeds per $\mathrm{m}^{2}$. All seed was obtained from Northrup and King Company and was mixed with nitrogen fixing bacteria prior to planting. Fertilizer was applied to each plot on June 10,1975 , with a hand operated broadcast spreader at the rate of $37-94-0 \mathrm{~kg} / \mathrm{ha}$ of $\mathrm{N}, \mathrm{P}_{2} \mathrm{O}_{5}$ and $\mathrm{K}_{2} \mathrm{O}$.

The average chemical composition of soil samples from the study area at Colstrip is given in Table 1 . Approximately $20 \mathrm{~cm}$ of topsoil with a sandy loam texture was applied over the spoil. The topsoil had about $0.5 \%$ orga nic matter and was low in nitrogen and phosphorus. The $\mathrm{pH}$ averaged 8.5. The spoil material beneath the topsoil was variable in texture and had less than $0.2 \%$ organic matter. The $\mathrm{pH}$ was between 8.2 and 8.4. The raw spoils material was also low in nitrogen and phosphorus.

The mean annual precipitation for the Colstrip area is $40.1 \mathrm{~cm}$ (DePuit and Coenenberg 1979). The annual precipitation totals for the years of 1975 through 1979 at Colstrip were 44.4, 40.8, 39.1, 57.8 , and $22.3 \mathrm{~cm}$ respectively. In 1975,1976 , and 1980 when sampling was conducted, precipitation values during the spring growing season (March through June) were $113 \%, 129 \%$, and $49 \%$ of the mean, respectively. Conditions were very favorable for plant growth in 1978 because spring growing season precipitation was $140 \%$ of the mean. Both 1979 and 1980 were years of severe spring drought. Irrigation was not used during any year of study.

Plant density samples were collected on June 14 and August 14, in 1975; June 22, 1976; and July 9, 1980 using $20 \times 20 \mathrm{~cm}$ square quadrats. Ten randomly placed quadrats were evaluated on each experimental unit on each sampling date. Plant canopy cover and frequency were estimated according to the methods of Daubenmire (1970) on June 22, 1976, and July 10, 1980. One 14-m sampling transect was established diagonally across each plot, and ten $20 \times 50-\mathrm{cm}$ quadrats were evaluated per transect at randomly selected points within each 1-meter interval. Sampling was not conducted at the top or the bottom 2-m of each plot. Aerial biomass was estimated June 22, 1976, by harvesting to ground level ten $0.25-\mathrm{m}^{2}$ quadrats per plot at random locations along the opposite side of the diagonal line used for cover sampling. No samples of any parameter were taken in a $1-\mathrm{m}$ buffer strip around each experimental unit. Density canopy cover and aerial biomass data were analyzed with a randomized complete block design (three blocks) using the procedures of Steel and Torrie (1960). Comparisons were made between the five species/varieties of legumes seeded using Newman-Keuls Test.

\section{Results and Discussion}

Plant density data collected in 1975, 1976, and 1980 are presented in Table 2. Eski sainfoin had significantly $(P<.05)$ the highest percent emergence followed by Lutana cicer milkvetch. Seedling density was measured again on August 14, 1975, to determine first year establishment. In terms of first growing season survival and/or increase Lutana cicer milkvetch and ranger alfalfa were superior to other species. These species have shown good first-year 
Table 1. Average chemical composition of soil samples from the study area at Colstrip, Mon.1

\begin{tabular}{|c|c|c|c|c|c|c|c|c|c|}
\hline Depth & $\begin{array}{c}\text { No. of } \\
\text { Samples }\end{array}$ & $\mathrm{pH}$ & $\begin{array}{l}\mathrm{NO}_{3}-\mathrm{N} \\
(\mathrm{ppm})\end{array}$ & $\begin{array}{l}\mathrm{PO}_{4}-\mathrm{P} \\
(\mathrm{ppm})\end{array}$ & $\underset{(\mathrm{ppm})}{\mathrm{K}}$ & $\begin{array}{c}\mathrm{Ca} \\
(\mathrm{meg} / \mathrm{l00g})\end{array}$ & $\begin{array}{c}M G \\
(\mathrm{meg} / 100 \mathrm{~g})\end{array}$ & $\begin{array}{c}\mathrm{Na} \\
(\mathrm{meg} / 100 \mathrm{~g})\end{array}$ & $\begin{array}{c}\text { E.C. } \\
(\mathrm{mmhos} / \mathrm{cm})\end{array}$ \\
\hline$(0-20 \mathrm{~cm})$ & 3 & 8.50 & 2.20 & .60 & 54.17 & 29.36 & 2.18 & .13 & .41 \\
\hline$(21-60 \mathrm{~cm})$ & 3 & 8.35 & 5.27 & .53 & 56.67 & 21.20 & 2.21 & .13 & .75 \\
\hline$(61-90 \mathrm{~cm})$ & 3 & 8.23 & 3.86 & .45 & 55.83 & 19.78 & 2.32 & .13 & .80 \\
\hline$(91-120 \mathrm{~cm})$ & 3 & 8.23 & 4.52 & .47 & 56.67 & 19.87 & 2.12 & .13 & .80 \\
\hline
\end{tabular}

'Soil samples were collected on November 17, 1974, prior to treatment application.

establishment in other studies at Colstrip (Sindelar et al. 1974; DePuit and Coenenberg 1979; Holechek 1981, 1982).

The density of spreader alfalfa and Lutana cicer milkvetch increased between August 14, 1975, and June 22, 1976. Survival of Eski sainfoin and ranger alfalfa was relatively high from 1975 to 1976. Birdsfoot trefoil suffered considerable mortality between 1975 and 1976 although survival of this species was high during the first year of seeding.

Data collected in 1980 showed drastic reductions in the density of all species. Both natural thinning and two consecutive years of drought probably account for the reduction in plant numbers. Lutana cicer milkvetch had a higher density than all species, although its density was statistically similar to that of spreader and ranger alfalfa. The percent survival of Eski sainfoin and birdsfoot trefoil was significantly lower $(P<.05)$ than that of the other three species. Density data alone, however, do not entirely indicate the relative effectiveness of the differe 1 legumes in revegetation of the mine spoils. Biomass, frequency, and canopy cover data provide an appraisal of soil stabilization effectiveness, plant distribution and plant vigor.

The density of invading species was significantly higher $(P<.05)$ on experimental units seeded to birdsfoot trefoil compared to other species in 1980. The average densities of invading species on birdsfoot trefoil, Eski sainfoin, Lutana cicer milkvetch, range alfalfa and spreader alfalfa plots in plants $/ \mathrm{m}^{2}$ were $43,19,11,8$ and 8 , respectively. Russian thistle (Salsola kali) was the primary invader found on the plots. It had an average density of 14 plants $/ \mathrm{m}^{2}$. The second most common invaders were spreader alfalfa and crested wheatgrass (Agropyon cristatum) each of which had an average density of 0.5 plants $/ \mathrm{m}^{2}$. The area surrounding the study was seeded to a 16 species mixure, native range occurred approximately $50 \mathrm{~m}$ to the north, and the study site was topsoiled. Howard and Samuel (1979) found that topsoil could provide a valuable source of native plant materials in reclamation of mined lands in Wyoming. However, the average density of native species on the plots was less than 0.1 plant $/ \mathrm{m}^{2}$ in the present study. These data suggest that natural revegetation on the mine spoils at Colstrip may be a very slow process even when a native seed source is available from nearby native range and in applied topsoil.

Legume canopy cover, frequency and aerial biomass data are presented in Table 3. In 1976 spreader alfalfa produced more aerial biomass than any other legume species/variety in the study. However, both Lutana cicer milkvetch and Eski sainfoin had higher plant density and frequency values. After two years of severe drought in 1980 only Lutana cicer milkvetch had higher canopy cover, frequency, and density values than spreader alfalfa. Spreader alfalfa is a rhizomatous, low growing variety of alfalfa that appears to have much potential for mined land revegetation at Colstrip because of its germination, survival, ground cover, and productivity characteristics. However, the effectiveness of this alfalfa variety in a seeding mixture remains to be evaluated.

Throughout the 6 years of study, Lutana cicer milkvetch maintained the highest plant densities and exhibited the most even distribution. In 1976 it was superceded by both Eski sainfoin and spreader alfalfa in canopy cover and productivity. However, in 1980 it had more canopy cover than the other legume selections. Because of its low, spreading and rhizomatous nature, initial evaluations of cicer milkvetch in the western United States were primarily concerned with its ability as a ground cover species to retard erosion (Carleton et al. 1971; Stroh et al. 1972). However more recently cicer milk vetch has also proven to be nutritious, palatable, non-bloating, and grazing tolerant (Stroh et al. 1972). Under the proper conditions cicer milkvetch appears to be capable of significant nitrogen fixation (Townsend et al. 1975; Rauzi et al. 1974). Unlike certain other members of the genus Astragalus, it apparently does not accumulate alkaloids to toxic levels. Research has also shown cicer milkvetch to perform well in species mixtures (Carleton et al. 1971; Stroh et al. 1972; DePuit and Coenenberg

Table 2. Legume density and survival in 1975, 1976, and 1980.

\begin{tabular}{|c|c|c|c|c|c|c|}
\hline Species' 1 & $\begin{array}{c}\text { Plants } / \mathrm{M}^{2} \\
\text { June } 14,1975\end{array}$ & $\begin{array}{c}\text { Plants } / \mathrm{M}^{2} \\
\text { August } 14,1975\end{array}$ & $\begin{array}{c}\text { Plants } / \mathbf{M}^{2} \\
\text { June } 22,1976\end{array}$ & $\begin{array}{l}\text { Plants } / \mathbf{M}^{2} \\
\text { July } 9,1980\end{array}$ & $\begin{array}{c}\% \\
\text { Emergence }\end{array}$ & $\begin{array}{l}\% \text { Survival } \\
\text { July } 9,1980\end{array}$ \\
\hline Lutana cicer milkvetch & $200^{b}$ & $254^{a}$ & $361^{a}$ & $32^{\mathrm{a}}$ & $37^{b}$ & $16^{\mathrm{a}}$ \\
\hline Spreader alfalfa & $172^{\text {bc }}$ & $148^{\mathrm{a}}$ & $248^{a}$ & $28^{a}$ & $32^{b c}$ & $16^{\mathrm{a}}$ \\
\hline Ranger alfalfa & $145^{\mathrm{bc}}$ & $191^{\mathrm{a}}$ & 156 & $23^{\mathrm{ab}}$ & $27^{b c}$ & $13^{\mathrm{a}}$ \\
\hline Eski sainfoin & $304^{a}$ & $241^{a}$ & $216^{\mathrm{bc}}$ & $15^{\mathrm{b}}$ & $57^{\mathrm{a}}$ & $5^{b}$ \\
\hline Birdsfoot trefoil & $113^{c}$ & $115^{a}$ & $32^{d}$ & $4^{c}$ & $21^{c}$ & $4^{b}$ \\
\hline
\end{tabular}

${ }^{1}$ Densities of legumc species/ varieties with different letters are significantly different $(P<.05)$ using Newman-Keuls Test. i

Table 3. Legume canopy cover (\%), frequency $(\%)$, and aerial biomass (kg/ha).

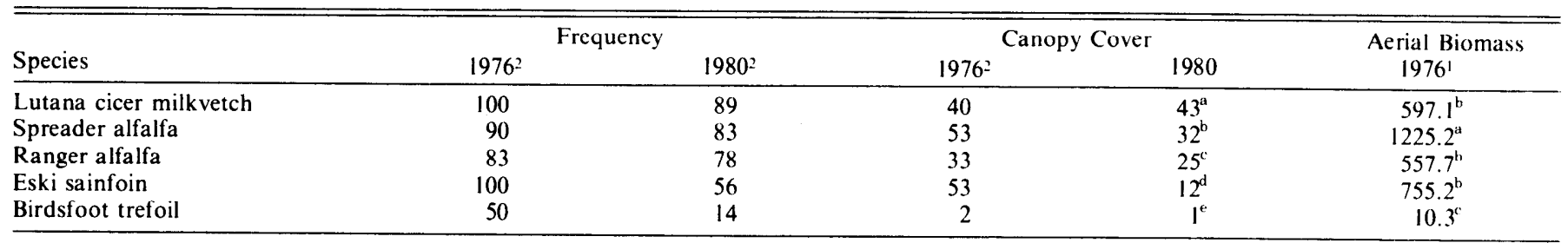

IValues followed by different letters are significantly different at $P<$ (Newman-Kuels Test). 
1979). The primary disadvantage of cicer milkvetch has been slow initial establishment due to both low germination and rate of spreading (Carleton et al. 1971; Montana Agricultural Experiment Station 1976). Research in the region of study concerning the establishment of Lutana cicer milkvetch has been contradictory. Studies conducted by Sindelar et al. (1973), Hodder and Atkinson (1974), and Dollhopf and Majerus (1975) have shown either low or nonexistent initial establishment. However, DePuit and Coenenberg (1979), and Holechek et al. (1981) reported Lutana cicer milkvetch had high initial and long term establishment in a 16 species mixture. Meyn et al. (1976) also reported that Lutana cicer milkvetch has typically either maintained itself or increased once established on mined lands at Colstrip. In the present study Lutana cicer milkvetch showed good initial establishment and superior long term growth even under conditions of severe drought when compared with other legumes.

Although Ranger alfalfa produced an adequate stand, it was inferior to spreader alfalfa and Lutana cicer milkvetch in emergence, survival, productivity, distribution, and canopy cover. This variety of alfalfa gives good persistence and lacks in aggressiveness when grown in grass mixtures (Ditterline et al. 1976). Holechek et al. (1981) reported that ranger alfalfa showed good initial establishment when planted in a four species mixture on mined lands at Colstrip.

Eski sainfoin showed good initial establishment and productivity in this study. However, between 1976 and 1980 this species declined drastically in both density and vigor. The long term survival of Eski sainfoin was inferior to Lutana cicer milkvetch, spreader alfalfa, and ranger alfalfa. Research regarding the establishment of Eski sainfoin has been conflicting in the Colstrip area. It has proven to be comparable or superior to ranger or Ladak alfalfa in terms of initial establishment and production in studies by Dollhopf and Majerus (1975), Hodder and Atkinson (1974), and Sindelar et al. (1973). In contrast Depuit and Coenenberg (1979) found that Eski sainfoin exhibited poor establishment, cover, and productivity compared to Ladak alfalfa and Lutana cicer milkvetch in a 16 species mixture planted at Colstrip. Research conducted by Meyn et al. (1976) on mined lands at Colstrip showed that with time Eski sainfoin decreased in a grasslegume mixture. Because it is nonbloating, nutritious, and initially productive, sainfoin is in some respects superior to alfalfa (Ditterline and Cooper 1975). However, one undesirable characteristic, particularly for mined lands plantings, is apparent limited nitrogen fixing ability (Townsend et al. 1975). Results from the present study and Townsend et al. (1975) suggest an additional disadvantage is lack of persistence, particularly during drought.

Birdsfoot trefoil was inferior to other legume species in all parameters evaluated. Other researchers working on mine spoils in the region have reported similar findings (Sindelar et al. 1973; Hodder and Atkinson 1974; Dollhoph and Majerus 1975).

\section{Conclusions}

Based on the evidence from this study, Lutana cicer milkvetch, spreader alfalfa and ranger alfalfa appear to be suitable legume species/varieties for revegetation of mined lands in the Colstrip area. Lutana cicer milkvetch may be a very valuable legume species for mined lands plantings in the Northern Great Plains region because of persistence, site stabilization qualities, forage value, nitrogen fixation benefits, relative drought tolerance, and eventual productivity. Although low initial establishment has been reported in other studies, Lutana cicer milkvetch did not manifest this problem in the present study. Eski sainfoin exhibited good initial establishment and productivity, but showed poor persistence. It has the added disadvantage of apparent inability to fix nitrogen. The prime utility of this species in mined land revegetation may hence be as a rapidly developing pioneer species with a major function of initially incrementing systemic organic matter content. Birdsfoot trefoil was found to be an unsuitable legume species for mined land plantings at Colstrip. Spreader alfalfa may be superior o ranger alfalfa for reclamation in the Colstrip area. However, more research is needed to evaluate the response of spreader alfalfa in a grass-legume mixture. In addition research is needed to evaluate the long term response of spreader alfalfa, ranger alfalfa, and Lutana cicer milkvetch under grazing pressure.

\section{Literature Cited}

Carleton, A.E., R.D. Austin, J.R. Stroh, L.E. Wiesner, and J.G. Scheetz. 1971. Cicer milkvetch (Astragalus cicer L.): seed germination, scarification and field emergence studies. Montana Agr. Exp. Sta. Bull. 655 , Montana State Univ., Bozeman. 21 p.

Daubenmire, R. 1970. Steppe vegetation of Washington. Washington Agr. Exp. Sta. Tech. Bull. 62, Washington State Univ., Pullman. 131 p.

DePuit, E.J., W.H. Willmuth, and J.G. Coenenberg. 1977. Plant response and forage quality for controlled grazing on coal mine spoils pastures Montana Agr. Exp. Sta. Res. Rep. 115, Montana State Univ., Bozeman. $74 \mathrm{p}$.

DePuit, E.J., J.G. Coenenberg, and W. Willmuth. 1978. Research on vegetation of surface mined lands. Montana Agr. Exp. Sta. Rep. 127, Bozeman. 165 p.

Depuit, E.J., and J.G. Coenenberg. 1979. Responses of vegetated coal strip mine spoils to variable fertilizer rates, longevity of fertilization program and season of seeding. Montana Agr. Exp. Sta. Res. Rep. 150, Bozeman. $81 \mathrm{p}$.

Ditterline, R.L., and C.S. Cooper. 1975. Fifteen years with sainfoin. Montana Agr. Exp. Sta. Bull. 681, Montana State Univ., Bozeman. 23 p.

Dollhopf, D.J., and M.E. Majerus. 1975. Strip mine reclamation research at Decker, Montana. Montana Agr. Exp. Sta. Res. Rep. 83. Montana State Univ., Bozeman. 42 p.

Farmer, E.E., R.W. Brown, B.A. Richardson, and P.E. Packer. 1974. Vegetation research on the Decker coal mine in southeastern Montana, U.S. Dep. Agr. Forest Serv. Res. INT-162, 12 p.

Hodder, R.L., and R.G. Atkinson. 1974. Peabody Coal Company, Big Sky Mine Reclamation Research. Montana Agr. Exp. Sta. Res. Rep. 48, Montana State Univ., Bozeman. 49 p.

Holechek, Jerry L. 1976. Initial effects of different species treatments and fertilizer rates on a mine spoils rehabilitation. Unpublished Masters Thesis. Montana State Univ., Bozeman. 91 p.

Holechek, Jerry L. 1981 . Initial establishment of four species on mine spoils. J. Range Manage. 34:76-77.

Holechek, Jerry L. 1982. Fertilizer effects on above- and below ground biomass of four species. J. Range Manage. 35:39-42.

Holechek, Jerry L., Edward J. DePuit, Joe G. DePuit, and Raul Valdez. 1981. Fertilizer effects on seeding mixture establishment on southeast ern Montana mined lands. J. Soil and Water Conserv. 36:39-42.

Holechek, Jerry L., Edward J. DePuit, Joe G. Coenenberg, and Raul Valdez. 1982b. Long term plant establishment on mined lands in southeastern Montana. J. Range Manage. (in press).

Howard, Gene S., and Marilyn J. Samuel. 1979. The value of fresh-stripped topsoil as a source of useful plants for surface mine revegetation. J Range Manage. 32:76-77.

Meyn, R.L., Sundberg, E.S. and R.P. Young. 1976. Research on reclamation of surface mined lands at Colstrip, Montana: Progress Report 1975 Montana Agr. Exp. Sta. Res. Rep. 101, Montana State Univ., Bozeman. $84 \mathrm{p}$.

Montana Agricultural Experiment Station. 1976. Perennial and biennial forage crop varieties for Montana. Montana Agr. Exp. Sta. Circ. 242, Montana State Univ., Bozeman. 55 p.

Rauzi, F., A. Herold, and L. Landers. 1974. Annual and perennial legume establishment trials in eastern Wyoming. Wyo. Agr. Exp. Sta. Res. J. 78, Univ. Wyoming, Laramie. 7 p.

Sindelar, B.W., R.L. Hodder, and M.E. Majerus. 1973. Surface mine land reclamation research in Montana. Res. Rep. 50. 122 p.

Sindelar, B.W., R. Atkinson, M. Majerus, and K. Proctor. 1974. Surface mined land reclamation research at Colstrip, Montana. Res. Rep. 69. Montana Agr. Exp. Sta., Montana State Univ., Bozeman. 98 p.

Steel, R.G., and J.H. Torrie. 1960. Principles and procedures of statistics. McGraw-Hill Book Co., New York. 532 p.

Stroh, J.R., Carleton, A.E., and W.J. Seamands. 1972. Management of Lutana cicer milkvetch for hay, pasture, seed, and conservation uses. Joint Res. J. of Soil Conserv. Serv.-Montana State Univ.-Univ. Wyoming, Res. J. 66, Montana State Univ., Bozeman. 17 p.

Townsend, C.E., G.O. Hinze, W.D. Ackerman, and E.E. Remmenga. 1975. Evaluation of forage legumes for rangelands of the Central Great Plains Colorado Agr. Exp. Sta. Gen. Ser. 942, Colorado State Univ., Fort Collins. $10 \mathrm{p}$. 